\title{
Negociação e Resistência escrava no século XIX: o caso de Nova Friburgo
}

\author{
Trading and slave resistance in the nineteenth century: the case of Nova Friburgo \\ Jéssica Magaldi Knupp.
}

Como citar esse artigo. Knupp JM. Negociação e Resistência escrava no século XIX: o caso de Nova Friburgo. Revista Mosaico. 2014 Jan./Jun.; $05 \quad$ (1): 21-29.

\begin{abstract}
Resumo
Este trabalho pretende realizar uma breve análise das dinâmicas sociais envolvendo senhor e escravo no contexto do Império Brasileiro. Tendo como base um processo-crime da fuga de escravos de uma fazenda da Vila de Nova Friburgo no ano de 1850, busca aproximar a lente de observação, a fim de compreender o escravo como agente de sua própria história. Entendendo que a diversidade étnica dos escravos representava uma variedade nas formas de compreender o sistema no qual estavam inseridos, busca pontuar as diferentes formas de entender a liberdade, apresentando as especificidades do sistema escravocrata na Vila de Nova Friburgo, onde resistência e negociação eram cotidianas. Palavras-Chave: Resistência escrava. Negociação escrava. Liberdade. Nova Friburgo. Fazenda Ponte de Tábuas.
\end{abstract}

\begin{abstract}
This study intends to show a brief analysis about social dynamics involving master and slave in the Brazilian Empire context. Based on an escape of criminal proceedings slave of a farm village of Nova Friburgo in 1850 , seeks to approximate the lens of observation in order to understand the slave as his own history agent. Understanding that the ethnic diversity of the slaves represented a variety in the ways of understanding the system in which they were entered, search punctuate the different ways of understanding freedom , presenting the specifics of the slave system in Nova Friburgo village, where resistance and negotiation were every day. Keywords: Slave Resistanc. Slave Trading. Slave in Nova Friburgo. Ponte de Tábuas Farm. Freedom.
\end{abstract}

\section{Introdução}

O presente artigo é uma breve elucidação a respeito da escravidão em Nova Friburgo. Seus resultados fizeram parte da pesquisa realizada para a obtenção do grau de Licenciada em História. Quando falamos de escravidão na cidade de Nova Friburgo fazemos menção a uma temática por muito tempo esquecida e embora alguns pesquisadores tenham se debruçado sobre o tema, ele ainda é pouco discutido na região.

Muito mais do que procurar comprovar a presença ou não de escravos na localidade, buscaremos apresentar um olhar diferenciado sobre as dinâmicas sociais da época, analisando as diferentes formas como os escravos percebiam e agiam diante do sistema escravocrata. A partir dos diferentes significados de liberdade que compreendem conceitos como negociação, resistência e rebeldia destacamos a pluralidade e a heterogeneidade presente no termo genérico "escravos".

Dessa maneira, vamos aproximar a lente de observação para o recorte micro a fim de entender como o contexto macro do Império Brasileiro influenciava a região da Vila de Nova Friburgo. Trata-se de um estudo regional que busca mostrar como o sistema escravocrata brasileiro foi absorvido pela colônia de suíços e alemães.

\section{A escravidão no cotidiano da Vila de Nova Friburgo}

Nova Friburgo foi criada por decreto para abrigar a primeira colônia estrangeira do Império Português, e não tardou a se tornar Vila. Primeiramente, as terras escolhidas abrigaram somente suíços, mas, em 1824, a colonização estrangeira ganhou o reforço dos imigrantes alemães. ${ }^{1}$ Segundo o historiador Jorge Miguel Mayer ${ }^{2}$ a vinda de estrangeiros tinha como objetivos povoar e tornar produtivas áreas de uma região ainda pouco explorada. As terras escolhidas para abrigar a colônia de suíços pertenciam a Cantagalo que, em 1817, já era um

1 MAYER, Jorge Miguel. A Criação de Nova Friburgo. In: ARAÚJO, João Raimundo de; MAYER, Jorge Miguel (ORG). Teia Serrana: Formação Histórica de Nova Friburgo. Rio de Janeiro: Ao Livro Técnico. p.31; pp. 19-46.

2 Idem. 
importante produtor de café com base na exploração de mão de obra escrava. Dessa forma, a formação da Vila de Nova Friburgo, em 1820, seria vital para ativar a rota comercial de mão-de-obra e outros produtos entre o Rio de Janeiro e o Centro Norte-Fluminense.

A expansão do café foi importantíssima na criação de uma elite requintada, que possuía títulos de nobreza, bastante influência na Província Fluminense e era grande acumuladora de capital. Contudo, os lucros não vieram somente do comércio do café, mas também, do comércio de escravos, principal força de trabalho nas agriculturas cafeeiras.

$\mathrm{O} 1^{\circ}$ Barão de Nova Friburgo chegou com seu irmão, na década de 1820, como sesmeiro em Cantagalo. Tornou-se um dos maiores cafeicultores da província possuindo em Cantagalo mais de dez fazendas, além de ter edificado o suntuoso Solar do Gavião, como mencionado e o Palácio do Catete, que se tornou sede do governo presidencial na República. Não bastasse isso, tinha muitas propriedades em Nova Friburgo, como o solar na Praça Getúlio Vargas, o Chalet do Country Clube e o prédio onde hoje se encontra o Sanatório Naval. Mas não foram somente os lucros do café que encheram a algibeira do Barão de Nova Friburgo. Sua acumulação de capital deveu-se ao fato de o Barão de Nova Friburgo figurar entre os maiores traficantes de escravos no Brasil. ${ }^{3}$

A escravidão era de extrema importância não só no Império Brasileiro de forma geral, como também, nas pequenas vilas como era o caso de Nova Friburgo, isto porque além de garantir mão de obra para a agricultura, ela era fornecida a partir de um comércio muito lucrativo, o tráfico negreiro. Sendo assim, a escravidão ajudou a construir a riqueza imperial, e em torno dela uma elite distribuída por todo o Império, como é o caso do Barão de Nova Friburgo, que fora descrito, na época, por Von Tschudi ${ }^{4}$ como um dos homens mais ricos de todo Brasil. E embora possa se tratar de uma afirmação exagerada, visto a extensão do território imperial e a impossibilidade de conhecer todas as fortunas do mesmo, não podemos negá-la totalmente, uma vez que se este viajante a descreveu desta forma, foi porque ficou bastante impressionado com ela. Desse modo, se torna evidente que a escravidão era protagonista em todo Império, e apesar de possuir peculiaridades regionais, ela fazia parte do cotidiano brasileiro, logo era corrente até mesmo em casos específicos, como o de Nova Friburgo. Portanto, a presença de escravos no cotidiano da Vila torna-se um fato inegável.

A escravidão fazia parte do cotidiano de Friburgo. Alguns escravos vendiam mercadorias na vila, como esteiras e produtos das roças, com autorização de seus senhores, mas deveriam apresentar licença, pois do contrário, seriam proibidos de comerciar. A maioria que circulava pelas ruas trabalhava "ao ganho", ou seja, vendiam mercadorias para seus senhores e tiravam uma pequena parcela dessas vendas. ${ }^{5}$

3 CORRÊA, Maria Janaína Botelho. Histórias e Memórias de Nova Friburgo: artigos publicados em A Voz da Serra. Rio de Janeiro: EDUCAM, p. 46.

4 TSCHUDI apud Côrrea, Maria Janaína Botelho. Op.Cit., p. 129.

5 CÔRREA, Maria Janaína Botelho. Op.Cit., p. 106.
Segundo Joseph Hecht que esteve em Friburgo no final de 1819 e início de 1820 ,

Os fazendeiros brasileiros podem viver, porém, uma vida muito sossegada, pois quase todo o trabalho é feito pelos escravos, que todo fazendeiro possui em grande quantidade, grandes e pequenos, homens e mulheres. Mais contentes ainda ficam, quando os escravos se reproduzem bastante, pois as crianças nascidas pertencem todas ao fazendeiro. ${ }^{6}$

Ainda, sob a ótica do mesmo autor, podemos analisar um pouco mais do cotidiano dos escravos no dia-a-dia da Vila, uma vez que Hecht descreve com detalhes a vida dos cativos que pôde observar. Segundo ele, os negros comiam uma comida feita separadamente e sentavam-se seminus no chão duro para comer e logo depois que comiam tinham que retornar ao trabalho. Trabalhavam sem camisas e não eram vistos com sapatos. Nos domingos e dias santos vestiam-se bem e iam à missa com seus senhores, mas ao retornar voltavam ao trabalho forçado. Joseph Hecht discorre, em alguns momentos, dizendo que os senhores não respeitavam o domingo de descanso e obrigavam os escravos a trabalhar. Relata que sentiu pena deles, por serem forçados a trabalhar, uma vez que não estão acostumados a isso. Nos relatos do autor podemos perceber, em algumas passagens, o que se pensava a respeito dos negros vindos da África para trabalhar no Brasil, de que forma eles eram vistos pelos europeus e pela cultura europeia. Segundo ele,

Já, desde a infância na África e agora na América, estavam acostumados a isso e não sentiam necessidade de outra coisa. Certamente nunca pensariam em dormir em leitos de cetim, nos quais os europeus se embrulham como bonecas. O que lhes davam era algo diferente: o trabalho rigoroso sob as ordens dum capataz igualmente rigoroso, que lhes tornava a vida amarga e desgostosa.

São forçados a trabalhar, mesmo não estando acostumados, pois na terra de origem deles não se trabalhava muito. Quem tinha residência fixa até produzia artigos de linho e algodão. Mas a maioria, composta de nômades, vagava de lugar em lugar, alimentando-se de peixe, caça, milho e outros frutos tropicais. O que agora precisam aprender na América deve ser obtido à base de pancadas, pois por serem, por natureza, rudes e incultos, tudo é muito difícil para eles, em especial a língua portuguesa e a religião católica totalmente diferente. ${ }^{8}$

Dessa forma podemos inferir que o choque cultural era grande, e que os negros eram vistos enquanto procedentes de povos não "civilizados" e sempre tratados com inferioridade diante da cultura europeia. Sendo assim, eles deveriam se adaptar, mesmo que à força, a nova realidade de trabalho forçado, religião diferente etc. Mas isso não significou que eles não fossem capazes de buscar, neste contexto de adaptações,

6 HECHT Joseph. A Imigrač̃o Sú́ç no Brasil 1819-1823: descrita por um participante. Traduč̃o: Armindo do L. Müller, $1^{\mathrm{a}}$ Ed., p.83, 152p. 7 Idem, p. 85 .

8 Idem, p. 90 
preservar parte de sua cultura de origem. Ainda segundo o mesmo autor, os fazendeiros davam aos negros um dia de presente, era a véspera da quarta-feira de cinzas, e só era comemorado pelos negros que estão no país, uma vez que enquanto "selvagens" podiam comemorar em um dia tão impróprio para os cristãos.

Nesse dia, o fazendeiro lhes dá uma comida melhor. Depois eles se reúnem para começar a grande festa. Um dos foliões negros canta ao som de um arco feito de cordas estiradas, preso ao corpo sobre uma cabaça e tocado por meio de uma vareta de metal com que se golpeia as cordas do arco. Com isso, os outros negros começam a dançar (as negras não ficam por perto e dançam num lugar separado). A maneira de dançarem é muito cômica. Eles correm uns contra os outros (será que devo contar isso?) até esbarrarem com força as barrigas, pulam para trás e giram bastante tempo num espaço pequeno, como se fossem um grande prato. Por seu grande entusiasmo, poder-se-ia inferir que a música é excelente, mas é difícil imaginar algo mais pobre. A música continua sempre no mesmo ritmo e o tocador canta ou resmunga junto com ela. Se um dos que dançam se cansa, um outro salta depressa para o seu lugar e faz os mesmos movimentos. Depois da dança vem a verdadeira comédia. Cada um tenta jogar lama no outro de surpresa ou então, como meninos de rua mal-educados, arremessar o outro na poça de lama e para isso gingam com tamanha agilidade, a ponto de não serem reconhecidos. ${ }^{9}$

Consultando a relação oficial de escravos falecidos nos anos de 1867 a $1889,{ }^{10}$ observamos que aqueles que faleceram com mais de 45 anos possuiam relato da sua origem e neles constavam as regiões de Benguela, Congo, Moçambique, Cabinda, Angola ou Africana; já na origem dos escravos mais jovens constava: Cantagalo, Bahia, Paraná etc. Dessa forma, unindo este dado a fala de Joseph Hecht, podemos perceber a diversidade que compunha os escravos brasileiros e friburguenses, mais especificamente. Essa mistura de culturas fez que com fossem criadas diferentes formas de perceber a escravidão e as dinâmicas sociais que a envolviam, principalmente pelos negros, mas também pelos senhores.

Compreendendo que a heterogeneidade do povo brasileiro era grande e que acontecia da mesma forma em Nova Friburgo, podemos analisar melhor as diferentes visões dos escravos sobre o sistema escravocrata. No entanto, não podemos negar a violência. Pelo contrário, precisamos entendê-la enquanto fato cotidiano da Vila de Nova Friburgo e para isso podemos continuar utilizando Hecht.

Segundo ele, a violência era comum. Em sua estada na Vila de Nova Friburgo, Hecht relatou a forma como os negros eram tratados e, mesmo que ele pertencesse à cultura europeia, entendendo que a mesma era superior a dos negros, ele repugnava os castigos e a forma violenta como os escravos eram tratados, nos

10 Relação Oficial de escravos falecidos - 1867-1889. In: Cadernos de Cultura. Notas para o estudo da presença do negro em Nova Friburgo. 116p. pp 67-84. Disponível no Centro de Documentação da presença do negro em Nova Friburgo. 116p. pp 67
Histórica Pró- Memória, na Fundação Dom João VI. contando que as fugas eram frequentes.

Com frequência, víamos passar por nossa cidade de Nova Friburgo negros fugidos que tinham sido capturados pelos caçadores contratados e que estavam sendo devolvidos aos donos. Quem capturasse um negro fugido e o devolvesse, recebia 40 florins, de acordo com a lei. Para quem se dedicava a essa maldita atividade, essa paga era suficiente. $\mathrm{O}$ negro que fugia pela primeira vez era espancado de forma horrível. Se fugisse uma segunda vez, era novamente espancado brutalmente, mas isso não era tudo: uma corrente era presa ao seu corpo, com uma parte pendendo para baixo, por meio da qual as pernas eram presas a uma argola. A corrente lateral era soldada a outra argola. Nessa miserável condição, com o corpo todo apertado, ele tinha de trabalhar e dormir. (...) Se o escravo fugisse pela terceira vez e fosse preso, era então transportado para o matadouro da cidade do Rio de Janeiro, onde todos os dias recebia cem chibatadas. Outros eram amarrados a um poste numa praça pública, inteiramente nus, e cruelmente surrados. ${ }^{11}$

Como podemos concluir a escravidão, assim como a violência inerente a ela, faziam parte do cotidiano da Vila de Nova Friburgo, que a princípio havia sido criada para abrigar uma colônia estrangeira de suíços. E, certamente, se as dinâmicas escravocratas se desenvolveram na Vila, logo se torna inquestionável o cotidiano das fugas e a frequência com que aconteciam. Este fato pode ser comprovado nas falas do autor acima citado, assim como, nas da historiadora Maria Janaína Botelho Côrrea, que nos relata sobre o Libambo.

Em Nova Friburgo, os escravos fugitivos capturados por capitães do mato eram mantidos no lugar denominado libambo. Ao arrepio da propriedade alheia, o libambo tinha sido regulamentado no art. 22 das primeiras posturas com a finalidade de se utilizar os escravos fujões em obras públicas, enquanto não fossem resgatados por seus senhores. (...) Denominava-se libambo, porque os escravos eram mantidos presos pelas mãos ou pescoços unidos pelo libambo, como era conhecida a corrente de ferro usada para prender os escravos. ${ }^{12}$

Compreendo a escravidão como parte do cotidiano da vila de Nova Friburgo e entendendo a violência como fato incontestável. Cabe enaltecer que, embora frequentes, as fugas não eram as únicas formas de buscar sair deste sistema. Pelo contrário, por existir uma grande heterogeneidade entre os escravos, cada qual entendia a escravidão de um modo, logo percebiam a liberdade de forma diferente. Sendo assim, nem sempre liberdade significava fugir do sistema.

\section{Negociação e resistência: diferentes tipos de liberdade}

Segundo o dicionário de filosofia de Nicola Abbagnano, o termo "liberdade" possui três significados fundamentais que se mantém ao longo da história do

11 HECHT, Joseph. Op. Cit, p. 89

12 CÔRREA, Maria Janaína Botelho. Op. Cit., p. 107. 
termo. São eles:

$1^{\mathrm{o}}$. Liberdade como autodeterminação ou autocausalidade, segundo a qual a liberdade é a ausência de condições e de limites; $2^{\circ}$. Liberdade como necessidade, que se baseia no mesmo conceito da precedente, a autodeterminação, mas atribuindo-a à totalidade a que o homem pertence (Mundo, Substância, Estado); $3^{\circ}$. Liberdade como possibilidade ou escolha, segundo a qual a Liberdade é limitada e condicionada, isto é, finita. ${ }^{13}$

Compreendendo que a primeira concepção entende que livre é aquilo que tem causa em si mesmo e a segunda, muito similar, ainda compreende a causa em si mesmo, mas atribuída ao todo e não somente ao indivíduo; vamos nos ater a terceira concepção para compreender as dinâmicas do período escravocrata. Isto porque o terceiro significado nos apresenta a liberdade como possibilidade, ou seja, como escolhas motivadas ou condicionadas. Dessa maneira, ainda segundo o dicionário de filosofia, a terceira concepção não identifica como livre aquele que é causa em si mesmo ou se identifica com uma totalidade que é causa em si mesmo, pelo contrário, livre é quem "possui em determinado grau ou medida, determinadas possibilidades". ${ }^{14}$

Sendo assim, precisamos esclarecer dois pontos importantes. Em primeiro lugar, precisamos entender o fato de que em todo o Império Brasileiro os escravos procediam de lugares diferentes, logo eram descendentes de etnias diferentes, sendo assim, eram pessoas que pensavam e agiam de formas diferentes, ou seja, possuíam diferentes visões de mundo e, portanto, compreendiam sua situação, enquanto escravo, de diversas formas. Um outro ponto a ser enaltecido é o fato desses escravos já chegarem ao Brasil, ou nascerem aqui e se depararem com um contexto pré-estabelecido.

Dessa maneira, os escravos possuíam escolhas, é claro que não eram escolhas do tipo ser escravo ou não, mas escolhas condicionadas, moldadas pelo sistema escravocrata, que garantia a essas pessoas as possibilidades de buscarem o que cada uma acreditava ser a liberdade. Ou seja, as pessoas que estavam aqui na condição de escravos eram limitadas pelo contexto escravocrata, que embora muito fechado não impossibilitava a busca por novas possibilidades. Dessa forma, essas pessoas com diferentes modos de compreender a situação, seres racionais e não apenas mercadorias, nem sempre percebiam a liberdade enquanto o fato de deixar de ser escravo.

Portanto, como parte integrante do Império Brasileiro, a Vila de Nova Friburgo fazia parte desse contexto de diferentes tipos de liberdade. Como já foi destacado anteriormente, a escravidão era parte do cotidiano de Nova Friburgo, logo a presença negra, escrava também moldava as dinâmicas sociais dessa

13 ABBagNANO, Nicola. Dicionário de Filosofia. São Paulo: Martins Fontes, p. 699-705. 14 Idem, p. 703 localidade. Sendo assim, é importante perceber o modo como os escravos agiam perante o sistema escravocrata e de que forma eles percebiam a liberdade. A fim de elucidar o que está sendo exposto, vamos analisar um relato do ano de 1821 enviado a Suíça pelos colonos de Nova Friburgo.

Falava-se de terras em uma região onde ninguém havia posto os pés. Vários colonos se reuniram com o fim de conquistá-la. Formou-se de 16 pessoas equipadas e munidas de viveres para vinte dias. Tomou-se um natural da terra para servir como batedor, pois é impossível penetrar nas matas virgens sem ter, pelo menos, um facão. Ao fim de oito dias de marcha alcançamos um quilombo, que é um refúgio de negros fugitivos que, para se livrarem da crueldade dos portugueses, vão viver em sociedade nas montanhas quase inacessíveis. Tais negros quando em número superior aos brancos, tornam-se muito perigosos. ${ }^{15}$

Esse é um relato da conquista das terras do Macaé, atual São Pedro da Serra, na qual podemos perceber a presença de um quilombo, ainda nos primórdios da criação de Nova Friburgo. Entendendo o quilombo como um local que habita uma sociedade que vive à margem da sociedade escravista do Império Brasileiro, formada por escravos fugidos do cativeiro, podemos entender o quilombo, assim como a fuga, como um ato de rebeldia. Ou seja, esses negros buscavam resistir abertamente ao sistema através de atos que o contrariassem. Dessa maneira, o quilombo e a fuga eram formas de resistência escrava de cativos que entendiam que a liberdade era viver da forma que achassem melhor, ou seja, fora do sistema que estava vigorando.

Mas, nem sempre a resistência se dava de forma aberta contra o sistema. Pelo contrário, na maioria das vezes a resistência se dava na forma de negociação, seja para buscar a tão sonhada alforria e deixar de ser escravo, seja para alcançar uma mobilidade social dentro do sistema. Dessa maneira verificamos algumas formas de liberdade: resistir através da rebeldia ou negociar para comprar a carta de alforria, ou ainda alcançar uma mobilidade dentro da hierarquia do sistema escravista, como por exemplo o cargo de feitor. Logo, nem sempre liberdade significava deixar de ser escravo por vias legais ou ilegais, podia significar também ascensão social por determinado período de tempo. E, dentro dessa discussão de diferentes tipos de liberdade, assim como, das formas de resistir ou negociar, é que pontuamos o caso da Fazenda Ponte de Tábuas.

A Fazenda Ponte de Tábuas esteve localizada ao norte da Vila de Nova Friburgo, onde hoje é o bairro Conselheiro Paulino, e vivenciou, no ano de 1850, um fato curioso na relação estabelecida entre escravo e senhor: trata-se da fuga de 19 escravos da fazenda. Ora, mas se fugas eram cotidianas na vila, assim como já constatado, por que este fato seria diferente? Para

15 CRETTON, Antoine. Carta para a Suíça. Transcrição: Raphael Jaccoud. Apud LOZADA, Gioconda. Op. Cit., p. 42 
responder a esse questionamento utilizo como base o livro "Os crimes da Fazenda Ponte de Tábuas"16 e como fonte principal o processo do caso manuscrito. ${ }^{17}$ Valendo ressaltar que a fonte está bastante tomada pelas ações do tempo e mesmo digitalizada é de difícil leitura, mas de imensa preciosidade. No entanto, é a mesma fonte utilizada no livro citado, cabendo sublimar que os autores trabalharam a fonte por mais de dois anos por isso utilizarei algumas partes transcritas em seu trabalho devido a dificuldade de leitura, o pouco tempo de acesso a mesma e a não existência de transcrição. Trata-se de um processo criminal de 276 páginas que relata a fuga de dezenove escravos da Fazenda Ponte de Tábuas, na Vila de Nova Friburgo, no ano de 1850, que teve como desfecho uma luta entre os escravos e os homens responsáveis por capturarem os fujões, o que acabou por acarretar na morte de um desses homens enquanto os outros ficaram feridos.

Diz João Antônio da Silva Ferreira administrador da Fazenda de Ponte de Tábuas, [?], pertencente ao Comendador Boaventura Ferreira Maciel, que na noite do dia 13 do corrente [Ano de nascimento do nosso Senhor Jesus Cristo de mil oitocentos e cinquenta $]^{18}$ das oito para as nove horas, uma porção de escravos da referida fazenda, que se achavam fugidos vieram a atacar... Feriram mortalmente ao feitor Francisco Antônio Ferreira, e ao camarada Luiz Crioulo e assassinaram barbaramente o Manuel Custódio de Carvalho Ferreiro que se achava trabalhando na dita fazenda. ${ }^{19}$

Eram 19 escravos que participaram da fuga, mas apenas quatro deles foram acusados e julgados pelo ato de rebeldia, são eles: "Antonio Pernambuco, Silvestre Crioulo, Valentim Moçambique e Constantino". ${ }^{20}$ Antônio Pernambuco fora acusado como líder e os outros três foram acusados de participarem das agressões e do assassinato. Ou seja, a Fazenda Ponte de Tábuas pertencia ao Comendador Boaventura Ferreira Maciel, mas era administrada por João Antonio da Silva Ferreira que apresentou a denúncia de que os escravos que estavam fugidos da Fazenda atacaram e feriram o feitor Francisco Antônio Ferreira e o camarada Luíz Crioulo e acabaram por assassinar Manoel Custódio de Carvalho Ferreiro, que trabalhava na Fazenda, enquanto os mesmos efetuavam uma busca pelos escravos.

Acharam o cadáver deitado de costas de cara coberta com um lenço de algibeira, a perna direita encolhida e os braços cruzados por cima do peito (...) Todos esses ferimentos foram feitos por instrumento cortante. Toda superfície do corpo mostra grandes e fortes contusões, principalmente o pescoço, estas contusões foram feitas por uma violência externa e estes ferimentos causaram a morte. ${ }^{21}$

16 LISBOA, Edson de Castro; MAYER, Jorge Miguel. Os Crimes da Fazenda Ponte de Tábuas: um estudo sobre a escravidão em Nova Friburgo no século XIX. Nova Friburgo.

17 PROCESSO-CRIME, Vila de Nova Friburgo, 1850. Arquivo Nacional n 1191 , maço 185.

18 Idem, p. 2.

19 Idem, p. 4.

21 LISBOA, Edson de Castro; MAYER, Jorge Miguel. Op. Cit., pp. 26-27.
O motivo da fuga foi apontado de modo semelhante no depoimento de todos os escravos. Eles reclamavam das condições violentas com que eram tratados pelo administrador da Fazenda, e, alguns, elogiavam o dono da Fazenda. Segundo os escravos, o administrador da fazenda criava motivos para castigálos, como contam no episódio do preto Basílio.

Tendo o dito preto Basilio relações ilícitas e amorosas com a preta Maria do Rosário que o ex-administrador da fazenda João Antonio com isso muito se zangou e que desde logo procurou um pretexto para castigar o dito preto e que uma noite estando todos eles reunidos no paiol entrou o dito administrador e disse que faltava um saco de feijão e que o dito preto Basílio é que tinha furtado e vendido na Vila que apesar do dito preto negar o administrador o mandou agarrar e amarrar no esteio onde o surrou e the deu depois mais pancadas entre elas uma estocada com um facão sobre as costelas, e algumas cutiladas na cabeça e que no dia seguinte o preto morreu. ${ }^{22}$

No entanto, o administrador da fazenda, assim como seus empregados, negaram a violência sem motivo e afirmaram que os escravos sempre foram respeitosos. Mas, que nos últimos tempos, não demonstravam vontade de servir. Afirmaram que "sempre tratou bem os pretos da fazenda castigando quando mereciam e fazendo-os trabalhar quando deveriam". ${ }^{23}$

Acusado de ser o líder da fuga, Antônio Pernambuco contou em seu depoimento que chegara na Fazenda há quatro anos onde trabalhava como feitor, mas, que foi destituído do cargo e colocado a ferro pouco antes da fuga. Segundo o administrador da Fazenda foi este escravo que induziu a fuga de todos os outros, pois não aceitava a demissão do cargo de feitor, que ocorreu porque Antonio Pernambuco estaria aprendendo feitiçaria e por ser muito ladrão. Fato que o escravo negou, afirmando ser apenas remédios para uma doença que tinha e que precisava buscá-los fora da fazenda uma vez que o administrador nunca the deu importância. Antônio Pernambuco fora condenado em grau máximo com pena de quatrocentos açoites aplicados na cadeia.

Diante da breve exposição dos fatos, podemos fazer apontamentos importantes. As dinâmicas sociais desenvolvidas na fazenda nos mostra uma violência extremada e inerente à escravidão, que é fato e por isso não cabe maiores discussões. No entanto, o processo nos apresenta uma nova percepção, a do escravo. Mesmo que tenha tido a interferência do escrivão, ou o medo das consequências, os escravos têm voz, contam a sua versão dos fatos, e se tratando de uma maioria analfabeta, este tipo de fonte é importantíssima. Sendo assim, é na contraposição das falas dos acusados e das ditas vítimas que conseguimos tecer o cotidiano das relações escravo-senhor e nos livrar das amarras que pretendem 
ver a escravidão apenas como violência e dominação. Isto porque percebemos o quão agentes de sua própria história eram os escravos, que não só compreendiam a sua situação, como buscavam negociá-la de diversas formas a fim de alcançar o que compreendiam enquanto liberdade.

Dentro desta perspectiva, podemos observar o fato de que dentro destas relações de poder, na qual vigorava a negociação, muitos escravos buscavam um certo tipo de mobilidade social atingindo o cargo de feitor e passando a atuar contra aqueles que compartilhavam da mesma posição que ele anteriormente, os escravos. E o rebaixamento fazia com que este escravo-feitor se rebelasse contra quem ele serviu fielmente, o senhor da fazenda. Ou seja, um jogo de interesses individuais que poderiam ou não mover uma grande massa, mas que com certeza ditavam as regras das relações sociais dentro do contexto escravista. Mas, diante de tamanha violência e poder sobre os escravos, o que pode ter motivado aos agentes deste caso, em especial, recorrerem à justiça e abrir um processo criminal contra os escravos? É óbvio que se tratando da morte de um homem livre é indispensável realizar a denúncia, no entanto, uma fuga seguida de reação dos escravos no ano de 1850 precisava ser contida em todos os âmbitos, vejamos o porquê.

De acordo com o censo realizado em 1834, ${ }^{24}$ na Paróquia de São João Baptista de Nova Friburgo, a população branca atingira 2615 pessoas, enquanto a negra era de 1987. Já no Censo realizado em 1851,25 na mesma localidade, por João Luis Vieira Cansansão Sinimbú, a população de escravos era de 1704 enquanto a população livre era de 3046. Embora não possamos confiar totalmente nesses dados por não sabermos ao certo a metodologia utilizada na contagem da população, eles são de extrema importância para termos uma noção da quantidade de escravos na região. E como podemos notar o número é crescente da década de 1828 até 1834 (Vide Tabela 1), mas decrescente ao longo dos anos seguintes. Contudo este fato não diminui o perigo que os escravos poderiam representar aos olhos da população branca.

Tabela 1. População da Freguesia de São João Batista de Nova Friburgo - 1828

\begin{tabular}{cccc}
\hline População & Machos & Fêmeas & Total \\
\hline Colonos & 426 & 398 & 824 \\
Brasileiros & 414 & 377 & 861 \\
Escravos & 861 & 411 & 1272 \\
Total geral & 1701 & 1186 & 2887 \\
\hline
\end{tabular}

Fonte. PEDRO, José Carlos; MAYER, Jorge Miguel. Vida e morte na colônia de Nova Friburgo: um estudo Demográfico.

24 Acervo Dr. Raphael Jaccoud. Notas para o Estudo da escravidão em Nova Friburgo. Cadernos de Cultura. Disponível no acervo Pró-memória.

25 Notas para o Estudo da escravidão em Nova Friburgo. Cadernos de Cultura. Disponível no 25 Notas para o Est
acervo Pró-memória
A Vila de Nova Friburgo era rota de passagem de viajantes, da produção de café, de comerciantes etc. e devido ao papel que assumiu pela proximidade com a Corte, as notícias circulavam rápido por lá. Além disso, os escravos daqui vinham de toda parte do Império, assim como alguns procediam da África. Segundo a historiadora Maria Janaína Botelho Corrêa, as notícias sobre as insurreições escravas ocorridas no contexto Nacional, como a Revolta dos Malês, e no contexto internacional, a Revolução do Haiti, chegaram à Vila, que, com um cotidiano escravocrata de fugas e castigos, ficou temerosa.

Em 1835, espalhou-se a notícia da possibilidade de uma insurreição de escravos em Friburgo e nos municípios vizinhos. Havia a denúncia de que um grupo de escravos do $3^{\circ}$ distrito do Rio Preto vagavam armados pelas fazendas e estradas, transmitindo aos cativos da região que haveria uma sublevação no dia 25 de dezembro.(...) Segundo relatos, o problema da rebelião se originava do fato de haver um excessivo número de escravos administrados por poucos feitores. Além do mais, alguns administradores das fazendas eram também escravos, o que os fazia temer ainda mais pela facilidade de apoderar-se do armamento. ${ }^{26}$

Isto pode ser confirmado pela criação do código de posturas da Vila de Nova Friburgo, em $1835,{ }^{27} \mathrm{em}$ caráter provisório emergencial até 1848 , que citava artigos sobre a captura de escravos fugidos e sobre a compra e venda de escravos.

Art. $18^{\circ}$ - Os capitães do mato, ou qualquer cidadão, que prender negro aquilombado e apresentar clareza de que o entregou ao juiz de paz, haverá do procurador da Câmara $8 \mathrm{mil}$ réis de captura (...). Art. $22^{\circ}$ - Toda pessoa em cujo o poder se achar algum escravo refugiado e quem o souber e não participar ao Juiz de paz ou inspetores de quarteirões no prazo de 48 horas, será multado de 10 a 20 mil réis ou 10 a 20 dias de prisão e de satisfazer o prejuízo que sofreu seu senhor. ${ }^{28}$

Embora o código de posturas provisório tratasse apenas sobre a questão da fuga e expusesse a escravidão apenas enquanto comércio, percebemos, que devido a quantidade de escravos na cidade, já começava a acontecer uma preocupação maior de supervisão e criação de leis que embasassem a escravidão local de acordo com a leis imperiais.

E mesmo que a população escrava tenha decaído, segundo os censos, até a década de 1850, a Vila ainda possuía um número considerável de escravos, e a união desses escravos poderia ser um problema. Dessa maneira, a fuga seguida de morte da Fazenda Ponte de Tábuas não significava apenas uma fuga comum, ou a denúncia da morte de um homem livre, significava também a união de vários escravos em prol de um mesmo objetivo: se livrar da violência extrema que o sistema estava the

\footnotetext{
26 CÔRREA, Maria Janaína Botelho. Op. Cit., p. 109.

27 As Primeiras Posturas Municipais da Vila de Nova Friburgo (1835). Transcrição: Carlos Jayme S. Jacooud. Disponível no Arquivo Pró-Memória. 28 Idem.
} 
impondo. Dessa maneira, não adiantava apenas punir esses escravos com castigos na própria Fazenda, eles precisavam ir a Julgamento Público, serem presos e castigados também na justiça pública a fim de servir de exemplo para que outros atos de rebeldia como esse não ocorressem.

Diante de tudo o que foi exposto vale destacar que a escravidão fazia parte do cotidiano da Vila de Nova Friburgo, assim como as fugas, resistências e negociações estavam presentes dentro desse contexto escravista. Portanto, como parte de um Império escravocrata, a Vila de Nova Friburgo era parte desse sistema e não é mais possível negá-lo. Além disso, é importante perceber essas dinâmicas sociais também do ponto de vista do escravo, tratá-lo como agente da sua própria história e não somente como mercadoria, porque, como foi visto, esses escravos tinham voz, e sabiam como fazer escolhas dentro das limitações do sistema, escolhas limitadas e diferentes porque não se tratava de um grupo homogêneo, mas sim de diferentes visões de mundo, diferentes compreensões do que a escravidão representava, assim como, diferentes significados de liberdade.

Dessa forma, ao pensar a temática escravidão se faz necessário uma compreensão plural dos conceitos empregados, uma vez que tentar homogeneizar a escravidão não é cabível tendo em vista a heterogeneidade cultural encontrada no Brasil. Sendo assim, devemos compreender os escravos dentro da sua tradição cultural, juntamente com o contexto micro no qual estavam inseridos, isto porque a temática escravidão ainda é muito abrangente e utilizar o recorte de casos específicos nos faz perceber as peculiaridades plurais que encontramos em todo o Império. Portanto, para compreender este sistema a partir das relações tecidas entre escravo e senhor, e não apenas do ponto de vista do dominador, em uma dicotomia dominador/ dominado, precisamos entender as diferentes visões de mundo, dos diferentes escravos, de culturas diferentes, de contextos diferentes, que percebiam de forma plural e diferenciada, liberdades, negociações e resistências dentro de um contexto preestabelecido de diferentes formas de escravizar e compreender a escravidão. Dessa maneira a generalização não é mais cabível, assim como, a compreensão do oprimido enquanto um ser incapaz de compreender e agir dentro do contexto no qual estava inserido. E um exemplo disto é o caso da Vila de Nova Friburgo aqui apresentado, que mostra os escravos de diferentes origens condicionados por um sistema preexistente, mas inteiramente capazes de fazer escolhas dentro do que compreendiam enquanto diferentes formas de liberdades.

\section{Considerações Finais}

Pensar a temática escravidão no Brasil é uma tarefa muito complexa visto a quantidade de estudos e pesquisas realizadas sobre o tema. Sendo assim, pesquisar escravidão é um trabalho que requer escolhas, uma vez que não é possível abordar em apenas uma pesquisa tudo o que já foi escrito sobre este tema até o momento. Em contrapartida a esta afirmação podemos observar o caso de Nova Friburgo que conta com pesquisas recentes sobre a temática, mas que embora ainda sejam poucas, quantitativamente falando, estão inseridas nos principais debates historiográficos.

Segundo o historiador João Raimundo de Araújo, ${ }^{29}$ as poucas pesquisas sobre a temática da escravidão podem estar relacionadas ao "mito da Suíça Brasileira" que foi criado, na década de 1960, por uma elite local, que buscou criar uma visão mítica de que Nova Friburgo era uma colônia estrangeira, uma espécie de "Suíça Brasileira", excluindo, assim, a presença negra da história friburguense. Além disso, foi criado no meio acadêmico local a ideia de que não havia fontes para o estudo da escravidão em Nova Friburgo. Mas estes paradigmas estão sendo rompidos com os trabalhos de historiadores locais que buscam inserir a escravidão nos debates sobre a história de Nova Friburgo, integrando a cidade no contexto nacional e nas principais discussões historiográficas sobre o tema.

Dentro dessas discussões podemos destacar que a partir da década de 1980 uma renovação historiográfica aplicou um novo olhar sobre a escravidão, buscando compreender o escravo como agente ativo no processo escravocrata, enfatizando conceitos como negociação, resistência, família escrava, entre outros; buscando entender como que os escravos compreendiam sua própria situação, tornando-os agentes ativos da sociedade escravista. ${ }^{30}$

Dentro desta vertente podemos destacar autores como João José Reis, ${ }^{31}$ que tenta compreender as estratégias, as escolhas e intenções dos cativos na sua luta diária contra a situação que se encontravam, mostrando que mesmo que o sistema limitasse a ação dos escravos, eles não estavam totalmente sem meios de buscar mudar sua situação imediata. Segundo o autor:

Uma imensa massa populacional que se transferiu
do continente africano para a colônia portuguesa não
pode ser analisada apenas como "força de trabalho"
e, por isso, muitos historiadores, hoje, procuram
discernir os caminhos, nem simples nem óbvios,
através dos quais os escravos fizeram história.

29 ARAÚJO, João Raimundo de. Nova Friburgo: a construção do mito da suíça brasileira (19101960). Niterói

30 ESCOSTEGUY, João Carlos Filho; SALLES, Ricardo. Questões Historiográficas IV Escravidão.In História da Historiografia Brasileira. Fundação CECIERJ: Rio de Janeiro, pp. 1-24.

31 REIS, João José; SILVA, Eduardo. Negociações e conflitos: a resistência negra no Brasil escravista. Rio de Janeiro: Companhia das Letras, $151 \mathrm{p}$. 32 Idem, p.13. 
Para esses autores, os escravos buscavam muito mais negociar sua situação de cativo do que lutar abertamente contra o sistema escravista, sendo assim, as rebeliões e revoltas seriam exceções dentro de um sistema marcado pelas negociações. Seguindo a mesma vertente, o historiador Sidney Chalhoub ${ }^{33}$ nos mostra que foi a negociação à tônica das relações escravistas ao longo do período escravocrata brasileiro, e não a luta aberta contra o sistema. Este autor busca compreender os sentidos da liberdade para os cativos, entendendo que estes sentidos eram forjados no cativeiro e, muitas das vezes, no ideal de o que vinha a ser um cativeiro justo.

Entre os historiadores locais podemos destacar o pioneirismo da historiadora Gioconda Lozada. ${ }^{34}$ Influenciada pela renovação historiográfica da década de 1980, a autora apresenta a importância do escravo nas pequenas atividades urbanas. A partir do estudo da Vila de Nova Friburgo, ela não só desmistificou a ideia de que a história desta região era somente a história da imigração europeia, como também contribuiu para o entendimento de que a escravidão fora importante não só nos grandes plantations, mas também, na produção de gêneros para consumo interno e nas atividades urbanas.

Dentro, talvez, do que venha a ser um novo momento sobre o estudo da escravidão no Brasil, podemos destacar Ricardo Salles ${ }^{35}$ que busca analisar a escravidão em suas relações estruturais mais amplas, mas sem deixar de analisar a vida escravista em nível local, uma vez que analisa as relações sociais entre senhores e escravos para compreender a importância da mão de obra escrava na construção do território de Vassouras, estabelecendo relação entre escravidão, classe senhorial e Estado Nacional a partir de uma análise micro. ${ }^{36}$ Salles buscou em sua obra seguir o que já havia sido desenvolvido no clássico de Stanley Stein, ${ }^{37}$ que a partir dos estudos das relações sociais e econômicas estabelecidas no importante município de Vassouras, mostrou como o contexto internacional influenciava o Império Brasileiro, entendendo que todas as relações sociais e políticas eram moldadas pela economia cafeeira.

Sendo assim, em consonância com os atuais debates sobre escravidão, o estudo aqui proposto buscou compreender os escravos como agentes ativos de sua própria história, dentro de uma perspectiva plural que buscou retirar o caráter genérico e homogêneo do conceito escravos e apresentá-los em suas diferentes formas de compreender o mundo, de pensar e agir, influenciados por suas diversas culturas. Portanto, compreender a diversidade é o que nos leva a entender

33 CHALHOUB, Sidney. Visões da liberdade: uma história das últimas décadas da escravidão na corte. São Paulo: Companhia das Letras.

34 LOZADA, Gioconda Op. Cit.

35 SALLES, Ricardo. E o Vale era o escravo: Vassouras, século XIX. Senhores e escravos no coração do Império. Rio de Janeiro: Civilização Brasileira.

36 ESCOSTEGUY, João Carlos Filho; SALLES, Ricardo. $O p$. Cit.

36 ESCOSTEGUY, João Carlos Filho; SALLES, Ricardo. Op. Cit. Wrobel. Rio de Janeiro: Nova Fronteira. os diferentes significados da liberdade para essas pessoas, que por muito tempo foram tratadas apenas como mercadorias incapazes de compreender a situação na qual se encontravam.

Deste modo, resistência, negociação, fuga, rebeldia, mobilidade social etc., fazem parte de um contexto de diversidade no qual as culturas, as possibilidades e as diferentes visões de mundo influem constantemente nas escolhas realizadas pelos cativos. À vista disso, a liberdade encontrava diferentes significados em um contexto onde, na maioria das vezes, a negociação determinava as dinâmicas das relações estabelecidas entre escravo e senhor muito mais do que a luta aberta contra o sistema. Deste modo, não podemos compreender a escravidão e as relações sociais estabelecidas dentro deste sistema apenas entendendo a liberdade como o ideal de não ser escravo. Pelo contrário, precisamos entendê-la enquanto um conceito plural, uma vez que enquanto existe uma diversidade cultural entre os escravos, logo, também existe uma diversidade na forma de compreender as diferentes liberdades.

Por tudo isto, o caso de Nova Friburgo vem exemplificar a discussão proposta sobre os diferentes tipos de liberdade, assim como reforçar a presença do negro na história desta localidade. Mas, longe de ser um trabalho completo e um tema esgotado, buscamos apontar algumas direções, hipóteses e possibilidades dentro do que propomos, valorizando os novos debates historiográficos sobre a temática escravidão, destacando a importância de olhares diferenciados sobre o tema e, principalmente, sobre a construção histórica e social de Nova Friburgo.

\section{Agradecimento}

Gostaria de fazer um agradecimento especial ao professor Me. Thiago de Souza dos Reis, e dedicar este artigo a ele, pela orientação competente, por acreditar no meu trabalho, me acolher e continuar me ajudando mesmo depois de formada. A você, meu muito obrigada!

\section{Referências}

\section{Fontes}

Arquivo Nacional. Processo-Crime: Fazenda Ponte de Tábuas. Vila de Nova Friburgo, 1850. № 1191, maço 185.

Centro de Documentação Histórica Pró-Memória - Fundação Dom João VI. As Primeiras Posturas Municipais da Vila de Nova Friburgo. Vila de Nova Friburgo, 1835. Transcrição: JACOOUD, Carlos Jayme S., 2004.

Centro de Documentação Histórica Pró-Memória - Fundação Dom João VI. Censo Demográfico. Paróquia de São João Batista de Nova Friburgo, 1834. Acervo Dr. Raphael Jaccoud.

Centro de Documentação Histórica Pró-Memória - Fundação Dom João VI. 
Censo Demográfico. Paróquia de São João Batista de Nova Friburgo, 1851.

Centro de Documentação Histórica Pró-Memória - Fundação Dom João VI. Padre Joye. População da Freguesia de São João Batista de Nova Friburgo, 1828. In: PEDRO, José

Carlos; MAYER, Jorge Miguel. Vida e morte na colônia de Nova Friburgo: um estudo Demográfico.

Centro de Documentação Histórica Pró-Memória - Fundação Dom João VI. Relação Oficial de escravos falecidos, Nova Friburgo, 1867-1889.

\section{Bibliográficas}

ABBAGNANO, Nicola. Dicionário de Filosofia. São Paulo: Martins Fontes, 2007.

ARAÚJO, João Raimundo de. Nova Friburgo: a construção do mito da suíça brasileira (1910-1960). Niterói, 2003.

; MAYER, Jorge Miguel (ORG). Teia Serrana: Formação Histórica de Nova Friburgo. Rio de Janeiro: Ao livro técnico, 2003, 318p.

Caderno de Cultura. Notas para o Estudo da escravidão em Nova Friburgo. Cadernos de Cultura. 1988.

CARDOSO, Ciro Flamarion e VAINFAS, Ronaldo (orgs.). Domínios da História: ensaios de teoria e metodologia. Rio de Janeiro: Campus, 1997.

CHALHOUB, Sidney. Visões da liberdade: uma história das últimas décadas da escravidão na corte. São Paulo: Companhia das Letras, 1990.

CORRÊA, Maria Janaína Botelho. Histórias e Memórias de Nova Friburgo: artigos publicados em A Voz da Serra. Rio de Janeiro: EDUCAM, 2011, p. 448.

CRETTON, Antoine. Carta para a Suíça. Transcrição: Raphael Jaccoud. Apud LOZADA, Gioconda. Presença Negra: uma nova abordagem da História de Nova Friburgo. EDUFF: Niterói, 1991, p. 42.

ESCOSTEGUY, João Carlos Filho; SALLES, Ricardo. Questões Historiográficas IV - Escravidão. In História da Historiografia Brasileira. Fundação CECIERJ: Rio de Janeiro, pp. 1-24.

HECHT, Joseph. A Imigração Suiça no Brasil 1819-1823: descrita por um participante. Tradução: Armindo do L. Müller, $1^{\text {a }}$ Ed., 2009, p.83, 152p.

LAFORET, Maria Regina Capdeville. A colônia de Nova Friburgo. In: ARAÚJO, João Raimundo de; MAYER, Jorge Miguel (ORG). Teia Serrana: Formação Histórica de Nova Friburgo. Rio de Janeiro: Ao Livro Técnico, 2003, 318 p. Capítulo 2, p.49, pp 47-78.

LISBOA, Edson de Castro. Café e escravidão em Nova Friburgo no século XIX. In: ARAÚJO, João Raimundo de; MAYER, Jorge Miguel (ORG). Teia Serrana: Formação Histórica de Nova Friburgo. Rio de Janeiro: Ao Livro Técnico, 2003, 318 p. Capítulo 3, pp 79-106.

; MAYER, Jorge Miguel. Os Crimes da Fazenda Ponte de Tábuas: um estudo sobre a escravidão em Nova Friburgo no século $X I X$. Nova Friburgo, 2008.

LOZADA, Gioconda. Presença Negra: uma nova abordagem da História de Nova Friburgo. EDUFF: Niterói, 1991.

MAYER, Jorge Miguel. A Criação de Nova Friburgo. In: ARAÚJO, João Raimundo de; MAYER, Jorge Miguel (ORG). Teia Serrana: Formação Histórica de Nova Friburgo. Rio de Janeiro: Ao Livro Técnico, 2003, 318 p. Capítulo 1, p.31, pp 19-46.

PEDRO, José Carlos; MAYER, Jorge Miguel. Vida e morte na colônia de Nova Friburgo: um estudo Demográfico.

REIS, João José. Rebelião escrava no Brasil: a história do levante dos Malês, 1835. São Paulo: Brasiliense, 1986.

; SILVA, Eduardo. Negociações e conflitos: a resistência negra no Brasil escravista. Rio de Janeiro: Companhia das Letras, 1989, $151 \mathrm{p}$.

SALLES, Ricardo. E o Vale era o escravo: Vassouras, século XIX. Senhores e escravos no coração do Império. Rio de Janeiro: Civilização Brasileira, 2008 .

STEIN, S. J. Vassouras: um município brasileiro do café, 1850-1900. Tradução Vera Bloch Wrobel. Rio de Janeiro: Nova Fronteira, 1990. 